\title{
Investigating English Language Policies in Saudi Higher Education English Departments: Staff Members' Beliefs
}

\author{
Suliman Mohammed Nasser Alnasser \\ Department of English Language and Literature, College of Arts, King Saud University, Riyadh, Saudi Arabia
}

Copyright $\mathrm{C} 2018$ by authors, all rights reserved. Authors agree that this article remains permanently open access under the terms of the Creative Commons Attribution License 4.0 International License

\begin{abstract}
The area of language policy and planning in educational settings has been attracting increasing attention in recent years. This study reports on an investigation into the beliefs of Saudi Arabian higher education department members concerning English Language Policies (henceforth ELPs). The focus was on their beliefs about ELPs outside the domain of the classroom and at department level. In these departments, English is normally used in a variety of department communication situations. The subject of how ELPs should be shaped and practised from staff members' perspectives has not yet been addressed in the literature. A mixed-method approach to data collection was adopted for this study. A total of 216 members of English departments from different regions (northern, southern, middle, western and eastern regions) and of different ranks (teaching assistants, lecturers, assistant professors, associate professors and full professors), specialities and genders participated in the study. An online survey comprising a background section and eight questions was provided, and 208 participants responded to it. Semi-structured interviews were conducted with seven male chairmen and one female vice chair. The findings of the study suggest that members of English departments have strong beliefs about ELPs and that they perceive such policies to be important and would therefore prefer them to be made explicit and official. It was also found that members favour a systematic department policy making process rather than adopting already designed policies from other parties (in other words, they prefer micro-level processing of ELPs). The implications of the findings for other departments and institutions are presented in this paper, as well as the limitations of the current study and recommendations for future research.
\end{abstract}

Keywords Beliefs, Higher Education, Language Policy and Planning, Language Use, Saudi English Departments

\section{Introduction}

Language policy and planning as a field has been attracting much attention in recent years. The issue of establishing rules for when and how a language is used in formal and/or non-formal situations has been of interest to several policy makers and researchers. These decisions can be made at macro-level by official authorities (i.e., by policy makers), or at micro-level by local communities that have direct exposure to them. In the Kingdom of Saudi Arabia, English is seen as a foreign language (i.e., EFL) that is accorded a high status by both the government and a considerable proportion of the society.

In existing research concerning English Language Policies (ELPs) within Saudi and non-Saudi educational contexts, the focus has been primarily on policies within the domain of the classroom [e.g., 1, 3, 12, 18, 28, 29, 32]. In the Saudi higher educational context, however, there are a considerable number of English departments across the country in which staff members hold different academic degrees in English-related specialist subjects, and some of them are non-Arabic speaking. It is therefore expected that English will be utilized outside the domain of the classroom and at department level. The question that arises in this case is what ELPs should these departments have from a micro-level perspective (i.e., from the perspective of English department members' beliefs). The aim of the current study was to explore the beliefs concerning ELPs of staff members from various Saudi English language departments at higher educational level.

\section{Background}

\subsection{Language Beliefs and Ideologies}

Before discussing language policy and planning in detail, it is important to situate language beliefs and ideologies within language policy and planning, since the two domains are closely related. In brief, Recento [23] suggests 
that the beliefs of individuals in a community can lead to the formation of a framework that then forms an ideology within a particular context. Van Dijk [33: p.8] defines language ideology as "the shared framework(s) of social beliefs that organize and coordinate the social interpretations and practices of groups and their members". Blommaert [5] suggests that ideology can have an effect on educational contexts in ways such as: influencing practical systems; stimulating the formation of identities, and having a significant impact on knowledge and learning. In the study referred to here, the beliefs of Saudi English department staff members from northern, southern, middle, western and eastern regions (and therefore, from different communities) were explored to make it possible to suggest a formulation of ELPs that will organize the use of English language at department level.

\subsection{Language Policy and Planning}

A brief survey of the literature on decisions made on language policy and planning around the world reveals that they are being made constantly. These decisions, either formal or informal, may impact entities at macro and/or micro levels. Before defining language policy and planning, it is important briefly to clarify the relationship between 'language policy' and 'language planning'. According to Johnson [15], the relation between the two concepts may not be as clear as it sounds. Although most researchers might share the view that the two concepts are closely linked but involve different activities, a few might have the perception that language policy is part of language planning [e.g., 16]. Others might see it the other way around (i.e., from the perspective that language planning is part of language policy) [e.g., 25]. Reaching a decision on this issue was beyond the scope of this study; therefore, there will be no further discussion on this matter here. For the purposes of the current study, the earlier view that language policy and language planning are closely linked but different activities was adopted.

There are several definitions of language policy and planning that support the view taken in this article. One of these is the definition given by Kaplan and Baldauf [16: p. xi], which states that: "the exercise of language planning leads to, or is directed by, the promulgation of a language policy by government (or other authoritative body or person). A language policy is a body of ideas, laws, regulations, rules and practices intended to achieve the planned language change in the societies, group or system". According to Cooper [8, p. 45], language planning refers to "deliberate efforts to influence the behavior of others with respect to the acquisition, structure, or functional allocation of their language codes". Spolsky [30] suggests that in a speech community there are three components of language policy: first, how language is practised; second, beliefs and ideologies held concerning the language and how it is used, and third, deliberate actions taken to alter any of the current language practices.

In an attempt to provide a comprehensive definition,
Johnson [15] defines language policy as a mechanism that can include official regulations with written documents intended to steer language use and function, among other things. It can also include unofficial implicit mechanisms linked to beliefs and practices about languages which may play a role in regulating how languages are used in a particular community or workplace [15]. In accordance with his definition, Johnson [15] suggests that language policies can be classified according to several types or categories. First, their genesis, i.e., LPs can be top-down macro-level policies in that they are developed by higher level authorities. These authorities can be the government itself or government agencies such as the ministry concerned with education or media. LPs can also be bottom-up micro-level policies, in that they are developed by whichever group of individuals have direct contact with them. Examples of these groups are individuals working together in a workplace, such as foreign language departments which may include speakers of other languages.

The second classification of language policies is means and goals, i.e., whether these policies are overt (announced to public) or covert (kept away from the public) [15]. In overt planning, some authorities intentionally publicize the policies they devise in order to facilitate their spread and adoption by other entities. On the other hand, on some occasions, governments adopt covert planning concerning the languages (or indigenous languages) used in its territories and keep these plans hidden for reasons such as to avoid provoking particular minorities or other communities or groups of people [24, 27]. The third classification concerns how these policies are documented: are they explicit - that is to say, are they documented in an official way (written or spoken); or are they implicit - that is to say, do they just occur spontaneously with no reference to official policies $[15,25]$ ? Whether a policy is explicit or implicit also refers to its degree of formality. Explicit policies are perceived or constructed as being official and therefore abided by by the people they were set for. Implicit policies, on the other hand, are seen to be non-official and, therefore, are flexible, in that if they were violated, there would be little concern.

The above discussion of the definitions of language policies and classifications of these policies is of importance to the focus of the current study. Common to both the definitions and classifications is the view that language policy and planning are practices that can be performed by an authoritative group of people other than the government, who at the same time practise them and can be directly impacted by them, and they can be grassroots generated. In other words, in micro-level planning a small group of people can work on planning their own language policies by setting their own rules and regulations that will influence their own behaviour and have an impact on language functions within their small community. Additionally, beliefs (concerning whether these ELPs should be covert or overt, implicit or explicit) 
of those members are to be considered as an integral component of devising ELPs. In relation to this interpretation, this study investigated the view of small communities (Saudi English departments) of various aspects of ELPs, among which was the question of who should be the authority to make these policies (i.e., should they be macro or micro decisions). It is argued that their beliefs should be considered if ELPs are to exist and succeed in their working community, a view that inspired the initiation of this research.

\subsection{Status of English in Saudi Arabia}

According to several researchers [e.g., 9, 13, 14], corpus, status and acquisition planning are the three types of language planning. Bright [6] describes these three types as 'dimensions of language planning'. The latter two are of relevance to the current study. Briefly, acquisition planning refers to what is being done in order to teach the targeted language. On the other hand, status planning refers to decisions that are made for a language to be used as an official language within a particular context [c.f. 34]. Bright [6: p. 311] gives a more elaborate description of status planning, saying that it "deals with initial choice of language, including attitudes toward alternative languages and the political implications of various choices".

Not only is Arabic the official language in Saudi Arabia, it is also seen as a holy language as it is the language of the Quran (Muslims' holy book) [11, 17, 21]. Religious language planning may have a tendency to treat the use of a holy language as sacred, and therefore, use it formally in every possible instance [17]. In this regard, the Saudi constitution states that Arabic is the official language of the country since it is the holy language and has been the language of its tribes for centuries. Although the constitution does not give any indication as to the use of other languages, in recent decades it is has become apparent that English, as a foreign language, is being accorded a high status. All of the above is related to both status and acquisition planning. In fact, English is the only foreign language that has gained the government's attention in its educational policy. With regard to acquisition planning, the English language is taught in public schools and is a compulsory requirement at most educational levels. For example, the government has included English courses at elementary level, a move which has been opposed by many Saudi educationalists and researchers, who claim that this will have a negative impact on the students' L1 (i.e., Arabic). At higher educational level, in most if not all BA degrees students have to study at least three credit hours in English as a requirement for completing a degree [1]. The government has also encouraged the establishment of international schools and at most of these schools English is the language of instruction, of communication inside and outside the classroom, and of textbooks. At community level, this type of school has been receiving increasing acceptance by Saudi families owing to, among other reasons, parents' desire for their children to master the English language. This trend in one way or another relates to the view that the more exposure to the language, the more acquisition of the language there will be [4, 19]. All this interest and attention being accorded to the English language by the Saudi government and the society helps to explain the continuous emergence of English programmes and institutions in governmental and private sectors in Saudi Arabia.

Status planning, on the other hand, is observed in Saudi Arabia and in different domains. Examples can be seen in official governmental and non-governmental documents where forms are most likely to have Arabic and English in the printed text (that includes an institution's label and title, and sometimes its logo) located at the top of forms and documents. It can also be seen when looking at public signs on roads and in various governmental agencies. Another example is the establishment of the Saudi broadcasting agency, which broadcasts a television channel completely in English (Saudi Channel 2), and the Saudi English radio that broadcasts in English as well. At public level, English is also given a high status and this can be observed from its use in menus in restaurants and on shop signs and the naming of some products that is in English. Although the majority of workers in Saudi Arabia are non-English speakers, who speak other foreign languages (e.g., Bengali, Urdu and Tagalog), the Saudi government has focused solely on the English language. It is possible that English is receiving the increasing attention owing its function as a lingua franca, a function that suggests speakers of other languages use English as a means of communication [10, 26]. The use of English as a lingua Franca concurs with the government's Vision 2030 (c.f. official Vision's website: http://vision2030.gov.sa/en), in which a shift in the economy and the attraction of international investments have been rigorously planned for, all of which considers English as a lingua franca.

\subsection{A Brief Overview on Saudi Arabia as an EFL Context}

It was mentioned earlier that more exposure to the language can lead to more acquisition [4, 19], but the question is how often can individuals be exposed to English in the Saudi context? English serves as a foreign language in Saudi Arabia (i.e., an EFL context), and EFL contexts are quite different from ESL contexts (English as a Second Language), in that English is not a language that is practised on a daily basis. Consequently, practising, and exposure to, English language in an EFL context are normally limited to unauthentic situations $[35,20]$, since there are insufficient opportunities for people to have encounters with English-speaking individuals. Such authentic situations are seen of essential importance for 
language acquisition, especially for adult learners [22, 31]. It has been argued that creating a suitable learning environment can have a positive impact on both motivation to learn and learning outcomes [7]. In this regard, Saudi English departments have staff members who are specialists in the English language; therefore, they are contexts that offer exposure to the language. However, this can be limited to the domain of the classroom, and beyond that most language use is in L1 (i.e., Arabic). This is different from an English department in an ESL context, where English is used inside and outside the classroom, providing much more exposure to authentic situations.

\subsection{Significance of the Study}

So far, studies investigating ELPs have been limited to the domain of the classroom [e.g., 3, 32, 28, 18, 29, 2]. The areas of communication beyond the classroom, staff-student language and communication in a Saudi context have not yet been investigated in conjunction with one another. It was deemed to be of value, therefore, to explore the beliefs of Saudi English department staff members in the light of the macro and micro levels of planning and the different classifications of policies discussed above, and taking into account the high status of the English language in Saudi Arabia. These beliefs could also be influenced by other, internal factors, such as the fact that these departments commonly hire teachers from foreign countries who do not speak Arabic (the official language of the country). In this regard, it seemed ethically sound to take this fact into account when considering the designing of ELPs, and to explore the subject of ELPs from staff members' perspectives. It was hoped that the findings of the study would provide concerned authorities (such as the Ministry of Education and Saudi universities) with useful insights into how to develop a framework for ELPs based on the preferences and inclinations of staff members of the departments concerned.

\section{Methodology}

The general area of the study was language policy and planning in higher education. The specific context of the present study was Saudi Arabian higher education English departments in the five main regions of the country (northern, southern, middle, western and eastern regions). The beliefs of these departments' staff members, who were from different backgrounds (ethnic and educational), regarding English language policies were explored with the aim of obtaining an overall conception of these beliefs. An attempt was made to reach staff members from all English departments in the country (these departments were affiliated to over 25 governmental and private institutions) to participate in the study. A mixed methods approach was adopted in order to obtain deeper insights into the subject under study and thus to reach more reliable conclusions concerning the issue than a single method would allow.
The instruments employed were an online survey and semi-structured interviews.

\subsection{Saudi English Departments}

Generally speaking, an English department in Saudi Arabia is affiliated to an institution (e.g., a college under the umbrella of a university, an unattached college or other types of institution). An English department has a chairman, is likely to have a vice chair for female affairs, and male and female members of staff. Those members can be of different academic ranks and specialisms. Their overall numbers vary according to the size of the institution and the beneficiaries they serve. English departments may offer different degrees and levels in the English language. The structural hierarchy normally works as follows: members of staff or students submit requests (for instance, requests for promotion, for permission to attend conferences, applications for rewards, applications for leave, and so on) to the chairman (or to the vice chair if they are female) and these requests, if necessary (that is, if the chairman cannot make the decision himself but in accordance with university protocols needs to redirect the request to a particular committee), are transferred to the designated committee comprising elected members of the department so the committee can discuss them and provide the chair with their recommendations. Then, if needed, the committee's recommendations are presented at the department council, which is seen as the supreme authority at department level. Decisions made at department level are seen as being high stakes decisions by all members. These decisions have to be reported to the upper council, i.e., the college's council, which in turn needs to report to an even higher council (i.e., the university's council). The above discussion has shown the possible hierarchies in language policy making (i.e., either top-down or bottom-up policy making) and the communication situations in which language is used between staff members.

\subsection{Research Questions}

The following research questions were designed for the study:

RQ1: What beliefs do Saudi English department staff members have concerning ELPS for their departments?

\section{RQ2: What beliefs do Saudi English department staff members have concerning the process of devising ELPS and the classifications of ELPS?}

\subsection{Participants}

A total of 216 participants (non-Saudis $=21.4 \%$ and Saudis $=78.6 \%$ ) were involved in the study. These participants were affiliated to English departments in over 25 universities around the country. Only academic staff who participate in teaching (and therefore are expected to be involved in administrative work) were included in the 
study, because they were likely to have participated in different communication situations that involved the use of the English language, and, consequently, able to provide insights into the subject under study. The participants held different degrees in subjects related to the English language, such as applied linguistics, theoretical linguistics, English literature and TESOL. They were also of different ranks, namely: teaching assistants, lecturers, language instructors, assistant professors, associate professors and full professors. They were from different nationalities, including Saudi Arabians and non-Arabic speaking participants. There were 144 female and 72 male participants.

\subsection{The Online Survey}

Since the aim of the study was to explore the views of staff members from different regions of the country, an online survey tool (offered by Google) was seen as the most efficient way of reaching them. This service makes it possible to reach a wide range of respondents at the same time; it is also possible for respondents to complete the survey using any device with access to the internet, such as smartphones and computers. The survey was publicized via social media and email, and it was open to receiving responses for the duration of two weeks. The purpose of the study was explained at the beginning of the survey, and it included a background section on the participants, inquiring about their gender, their specialist subject, the position they held and the region they were working in. After that they were asked to respond to eight questions. A Likert scale (strongly agree, agree, not sure, disagree and strongly disagree) was adopted for the first five questions, and the remaining questions were given their own appropriate scales. The survey statements were as follows:

1. Having departmental language policies on when to use English is a must.

2. Members of a department should abide by its English language policies.

3. Staff members' familiarity with department language policies, if any, will contribute to accomplishing institutional goals.

4. My institution should require our department to have clear language policies regarding English use.

5. The head of my department should ensure that ELPS are put into practice.

6. The authority(ies) that should be making department language policies is/are:
a) The Ministry of Education
b) The institution
c) The department
d) Other

7. Language policies set by my department should be:
a) Written
b) Verbal
c) Other

8. My department's language policies should be:
a) Agreed upon by the department council
b) Set by some members informally
c) Other

\subsection{Interviews}

Semi-structured interviews were utilized since they allow the researcher to obtain elaborations from interviewees where necessary. It was possible to interview eight subjects who were later assigned codes for the purposes of analysis and for ethical reasons (see Table 1). Since the interviewees were located in different regions of the country, most of the interviews were carried out over the phone, and only some of them were face-to-face. An attempt to consider male and female interviewees from different regions was made. However, owing to cultural restrictions, it was only possible to interview one female participant. The eight participants came from the five main regions of Saudi Arabia. These interviewees were asked to answer three questions, namely:

1. When should English be used outside the classroom?

2. Who should have the authority to make ELPs for English departments?

3. How important are ELPs in English departments?

Table 1. Interviewees' information and codes

\begin{tabular}{|c|c|c|c|c|}
\hline No. & $\begin{array}{c}\text { Interviewees } \\
\text { Codes }^{1}\end{array}$ & Gender & $\begin{array}{l}\text { Academic } \\
\text { Rank }\end{array}$ & $\begin{array}{l}\text { Experience in } \\
\text { Current Post }\end{array}$ \\
\hline 1 & $1 \mathrm{~A}$ & Male & $\begin{array}{l}\text { Assistant } \\
\text { Professor }\end{array}$ & 1 year \\
\hline 2 & $1 B$ & Female & $\begin{array}{l}\text { Assistant } \\
\text { Professor }\end{array}$ & 4 years \\
\hline 3 & $1 C$ & Male & $\begin{array}{l}\text { Assistant } \\
\text { Professor }\end{array}$ & 3 months \\
\hline 4 & $2 A$ & Male & $\begin{array}{l}\text { Assistant } \\
\text { Professor }\end{array}$ & Three years \\
\hline 5 & $3 A$ & Male & $\begin{array}{l}\text { Assistant } \\
\text { Professor }\end{array}$ & Two years \\
\hline 6 & $4 A$ & Male & $\begin{array}{l}\text { Assistant } \\
\text { Professor }\end{array}$ & Six months \\
\hline 7 & $4 B$ & Male & $\begin{array}{l}\text { Associate } \\
\text { Professor }\end{array}$ & $\begin{array}{l}\text { Three and a } \\
\text { half years. }\end{array}$ \\
\hline 8 & $5 A$ & Male & $\begin{array}{l}\text { Assistant } \\
\text { Professor }\end{array}$ & Two years \\
\hline
\end{tabular}

\subsection{Limitations of the Study}

There were some limitations to this study, one of which was the difficulty of reaching a wider range of participants. Although the method of publicizing the survey was seen as appropriate, the response rate was not as high as expected. Therefore, future studies may need to consider how to involve a larger number of participants. Furthermore, owing to cultural restrictions, reaching additional female interviewees was difficult. Future studies are therefore encouraged to interview more female members. Finally, it was not possible to compare male and female beliefs in this

1 The numbers in these codes refer to the regions, and the letters refer to the different respondents in one region. 
paper owing to limitations of space; therefore, it is recommended that future research investigates gender-related differences of opinion in this regard.

\section{Results and Discussion}

In this section the results of the survey and the interviews are presented. With regard to the findings from the interviews, the interviewees' codes are given in an attempt to provide the reader with a more comprehensible picture of the nature of the responses. On the other hand, frequencies are given for the survey results, as they were seen to be the most appropriate means for analysis.

\subsection{Interview Results}

\subsubsection{When Should English Be Used outside the Classroom?}

In response to this question, six interviewees (namely, interviewees 1A, 1B, 2A, 3A, 4B and 5A) were in favour of using English in all possible domains while expressing minor reservations. The interviewees were of the opinion that English should be used at all times unless: it was impossible to do so, such as when responding to official letters written in Arabic (1A); in emotional instances (e.g., expressing condolences, conversing with a sick member of staff) (1B); when posting announcements aimed at students who may have low English proficiency levels (3A), and when dealing with Arabic documents in order to save time (4B). The above findings suggest that these respondents and their departments use English extensively outside the domain of the classroom and prefer to utilize English in most if not all possible situations. In this regard, it is possible that, since all members of staff hold degrees in English language-related subjects, the domain of the department is the only available place to practise English professionally (see Section 2.4).

Interviewee 4A stated that English should be used with students only on formal occasions, such as during a workshop or a seminar. Also, interviewee 1C stated that there was no need to use English outside the classroom since there were no non-Arabic speaking members of staff in his department and all official documents were written in Arabic.

\subsubsection{Who Should Have the Authority to Make ELPs for English Departments?}

All eight interviewees clearly stated that the departments should be the only authority to make its ELPs. Therefore, their beliefs regarding ELP making should be dealt with at the micro-level (see Sections 2.1 and 2.2). Justifications that were provided were, for example, because the department knows which policies best suit it $(1 \mathrm{~A}, 2 \mathrm{~A}$ and $5 \mathrm{~A}$ ); it is an internal issue (4A and $5 \mathrm{~A}$ ); the department has experts in the field of English language unlike other councils (e.g., college council) who are not likely to be specializing in English (3A and 4B); the department can ensure the success of ELPs since members of staff will agree on them (1C), and the department can develop them, practise and alter them if necessary, and then generalize them at national level. With regard to these responses, it does indeed seem logical to give English departments the authority to make their own ELPs, since they have the appropriate skills and expertise to design what will be beneficial to, and applicable in, a working environment.

\subsubsection{How important is it for ELPs to Exist in English Departments?}

All eight interviewees reported that the existence of ELPs is important in Saudi English departments. Reasons for their views varied: for example, ELPs can: create a suitable working environment (1A, 1B, 5A and 4B); create a suitable learning environment for students ( $1 \mathrm{~A}$ and $5 \mathrm{~A})$; allow staff members to maintain their linguistic competence (1A and 5A); provide unified, easy to follow regulations on when to use English in different department encounters that will ensure consistency (1C); encourage members of staff to use English more often (4A); reduce the tension between supporters and opponents of having ELPs by agreeing on them together (3A); and show how considerate we are to the non-Arabic speaking members of $\operatorname{staff}(2 \mathrm{~A})$.

\subsection{Survey Results}

\subsubsection{Having Departmental Language Policies on When to Use English Is a Must}

Participants were asked whether or not they thought having ELPs was essential, and the majority strongly agreed (55.6\%). Another large proportion (36\%) agreed with the notion (see Table 2). The fact that such a large proportion (91.6\%) agreed on the importance of having ELPs in their departments suggests that such policies could have a positive impact on their English departments. It is also possible that staff members in Saudi English departments find themselves in departmental situations/encounters where it is not clear whether English or Arabic should be used. Additionally, there could be some members of staff who do not speak Arabic and would like there to be policies that state that English should be used in particular in-department situations, a view which is in line with some of the responses to the interview questions (see Section 4.1.3). The data may also suggest that having ELPs may meet one of others' (such as institution leaders') expectations of English departments which is that English should be used within the domain of the department.

By contrast, a very small proportion of the respondents $(5.7 \%)$ indicated their uncertainty about the necessity of having ELPs, and an even smaller proportion (2.4\%) disagreed with the notion. These data suggest that these 
two proportions (a total of $8.1 \%$ ) did not accept having ELPs and, therefore, did not see the importance of having ELPs, as did the other respondents.

Table 2. Having ELPs is a must

\begin{tabular}{|c|c|c|c|}
\hline Values & Frequency & Per cent & Valid Per cent \\
\hline Strongly agree & 116 & 55.6 & 55.6 \\
\hline Agree & 75 & 36 & 36 \\
\hline Not sure & 12 & 5.7 & 5.7 \\
\hline Disagree & 5 & 2.4 & 2.4 \\
\hline Strongly disagree & 0 & 0 & 0 \\
\hline Total & $\mathbf{2 0 8}$ & $\mathbf{1 0 0 . 0}$ & $\mathbf{1 0 0 . 0}$ \\
\hline
\end{tabular}

\subsubsection{Members of a Department Should Abide by Its} English Language Policies

The majority of the participants $(56.1 \%)$ strongly agreed and a large proportion (36\%) agreed with this statement (see Table 3). Thus, $92.1 \%$ of the total number of participants agreed that when there are ELPs staff members should abide by them. It thus appears that ELPs are seen as being important to Saudi English departments and their staff members. A very small number of respondents $(7.6 \%$ of the population) either disagreed with the statement or were not sure about it, which may suggest their lack of acceptance of the necessity for having ELPs, or, which seems more likely, that they saw no need for having them at all. This is understandable, since the country's language is Arabic and the majority are Arab speakers.

Table 3. Abiding by ELPs

\begin{tabular}{|c|c|c|c|}
\hline Values & Frequency & Per cent & Valid Per cent \\
\hline Strongly agree & 117 & 56.1 & 56.1 \\
\hline Agree & 75 & 36 & 36 \\
\hline Not sure & 13 & 6.2 & 6.2 \\
\hline Disagree & 3 & 1.4 & 1.4 \\
\hline Strongly disagree & 0 & 0 & 0 \\
\hline Total & $\mathbf{2 0 8}$ & $\mathbf{1 0 0 . 0}$ & $\mathbf{1 0 0 . 0}$ \\
\hline
\end{tabular}

\subsubsection{Staff Members' Familiarity with Department} Language Policies, If Any, Will Contribute to Accomplishing Institutional Goals

In response to this statement, a large proportion (48.4\%) of the respondents strongly agreed, in addition to another large proportion (43.2\%) who agreed with it (see Table 4), which means that a total of $91.6 \%$ of the population were of the opinion that familiarity with ELPs can contribute to accomplishing institutional goals. This suggests that ELPs can have a positive impact at institutional level and, therefore, ELPs do have importance in English departments. It also suggests that if ELPs exist, staff members should become aware of them. A very small number of respondents either disagreed with the statement or were not sure about it, forming $8.1 \%$ of the population, which may be because they were not, or had not been exposed to, ELPs and, therefore, did not appreciate their significance. It could also mean that these participants did not attach any importance to having ELPs at department level.

Table 4. Staff members' familiarity with ELPs' impact on institutional goals

\begin{tabular}{|c|c|c|c|}
\hline Values & Frequency & Per cent & Valid Per cent \\
\hline Strongly agree & 101 & 48.4 & 48.4 \\
\hline Agree & 90 & 43.2 & 43.2 \\
\hline Not sure & 14 & 6.7 & 6.7 \\
\hline Disagree & 3 & 1.4 & 1.4 \\
\hline Strongly disagree & 0 & 0 & 0 \\
\hline Total & $\mathbf{2 0 8}$ & $\mathbf{1 0 0 . 0}$ & $\mathbf{1 0 0 . 0}$ \\
\hline
\end{tabular}

4.2.4. My Institution Should Request That Our Department Has Clear Language Policies Regarding English Use

The majority ( $56.6 \%$ ) of the participants strongly agreed with this statement, with an additional large proportion $(33.6 \%)$ agreeing with it (see Table 5). This made a total of $90.2 \%$ of the respondents who agreed that English departments should have ELPs as a requirement. This suggests that these respondents would like their English departments to have ELPs as an official practice that is enforced by a higher administration. It also suggests that because ELPs can have positive impact at the department level, it is necessary to have them and make them official. This finding could also mean that respondents' departments may need to be encouraged by their institutions to make and practise ELPs. A very small proportion of the respondents $(9.5 \%)$ either disagreed or were not sure about the statement, which suggests that they rejected the notion of making ELPs official or of having them enforced by any party.

Table 5. Institution's requirement for having ELPs

\begin{tabular}{|c|c|c|c|}
\hline Value & Frequency & Per cent & Valid Per cent \\
\hline Strongly agree & 118 & 56.6 & 56.6 \\
\hline Agree & 70 & 33.6 & 33.6 \\
\hline Not sure & 17 & 8.1 & 8.1 \\
\hline Disagree & 3 & 1.4 & 1.4 \\
\hline Strongly disagree & 0 & 0 & 0 \\
\hline Total & $\mathbf{2 0 8}$ & $\mathbf{1 0 0 . 0}$ & $\mathbf{1 0 0 . 0}$ \\
\hline
\end{tabular}

4.2.5. The Head of My Department Should Ensure That ELPs Are Put into Practice

In response to this statement, the majority of the respondents $(61.4 \%)$ strongly agreed and another considerable proportion of them (31.2\%) agreed (see Table 6). Thus, $92.6 \%$ of the total number of participants wanted their chairmen to ensure that ELPs were put into practice. This would suggest that these respondents have a desire to have and to practise ELPs, to the extent that they are being enforced by the chairmen. It may also indicate that members of English departments perceive ELPs to be of 
importance at department level. Only a very small proportion $(7.1 \%)$ either disagreed or were not sure about the notion of having their chairmen ensuring the practice of ELPs, which may suggest that they were opposed to the idea of having ELPs in their English departments.

Table 6. Ensuring practice of ELPs by the chairman

\begin{tabular}{|c|c|c|c|}
\hline Value & Frequency & Per cent & Valid Per cent \\
\hline Strongly agree & 128 & 61.4 & 61.4 \\
\hline Agree & 65 & 31.2 & 31.2 \\
\hline Not sure & 11 & 5.2 & 5.2 \\
\hline Disagree & 4 & 1.9 & 1.9 \\
\hline $\begin{array}{c}\text { Strongly } \\
\text { disagree }\end{array}$ & 0 & 0 & 0 \\
\hline Total & $\mathbf{2 0 8}$ & $\mathbf{1 0 0 . 0}$ & $\mathbf{1 0 0 . 0}$ \\
\hline
\end{tabular}

\subsubsection{The Authority(ies) That Should Be Making}

Department Language Policies Is/Are:

\section{a) The Ministry of Education \\ b) The institution \\ c) The department \\ d) Other: .........}

The respondents were asked who they thought should have the authority to make the ELPs that would be practised in their English departments, and their responses varied (see Table 7). The largest proportion (36.3\%) thought that the department should be the only authority to make such policies; in other words, they wanted them to be micro level ELPs (see Section 2.2). In this regard, it does seem logical that the department should be the only body that has the authority to make ELPs, since they are the concerned community that will have direct contact with them; thus, they know best what is suitable for them, which may result in ensuring that policies are devised that will have a positive impact on the department. This proportion of the respondents did not seem to want the university to be involved in making these policies, which is understandable, since not all members of staff working for Saudi universities speak English or have experience in devising language policies.

Another relatively small proportion (18.2\%) reported that the university and the department together should have the authority to make ELPs, i.e., macro and micro level policies (see Section 2.2). It is possible that they saw the necessity for collaboration between these two parties in making these policies. Also, such collaboration may result in meeting the expectations and standards of the university as well as the department in regard to which language policies should be practised. A small proportion (16.7\%) reported wanting the Ministry of Education, the university and the department to be involved in making ELPs. From a general perspective, it is logical that these three parties should all be involved in making language policies; however, involving the Ministry of Education may slow down the whole process of making such policies owing to the bureaucratic nature of administration: the approval process would become more difficult and time-consuming and altering or cancelling any approved policies could be difficult (see Section 3.1 for details on the hierarchical nature of administrative processing). A smaller proportion $(13.9 \%)$ believed that the university should be the only authority to make ELPs. It could be that those respondents had more faith in their institution than in their departments, which may be because these respondents belonged to newly established departments or because their staff members had a lack of experience of ELPs. Other very small proportions of the respondents reported their desire to have both the Ministry of Education and the university involved (8.1\%); the Ministry of Education only (4.3\%), or the Ministry of Education and the department only (1.9\%).

Table 7. Authorities for making ELPs

\begin{tabular}{|c|c|c|c|}
\hline Values & Frequency & Per cent & Valid Per cent \\
\hline The department & 76 & 36.3 & 36.3 \\
\hline The Ministry of Education & 9 & 4.3 & 4.3 \\
\hline $\begin{array}{c}\text { The Ministry of Education; } \\
\text { The department }\end{array}$ & 4 & 1.9 & 1.9 \\
\hline $\begin{array}{c}\text { The Ministry of Education; } \\
\text { The university }\end{array}$ & 17 & 8.1 & 8.1 \\
\hline $\begin{array}{c}\text { The Ministry of Education; } \\
\text { The university; The } \\
\text { department }\end{array}$ & 35 & 16.7 & 16.7 \\
\hline $\begin{array}{c}\text { The university } \\
\text { The university; The } \\
\text { department }\end{array}$ & 38 & 18.2 & 18.2 \\
\hline Total & $\mathbf{2 0 8}$ & $\mathbf{1 0 0 . 0}$ & $\mathbf{1 0 0 . 0}$ \\
\hline
\end{tabular}

4.2.7. Language Policies Set by My Department Should Be:

\section{a) Written \\ b) Verbal \\ c) Other}

In response to this statement, the majority of the respondents $(96.4 \%)$ reported their desire to have written policies. This may be because they thought written policies were more official, and that staff members would be more likely to be aware of and practise them, since they could refer to them in written form (see Table 8). This may also indicate that members of staff in Saudi English departments are serious about having ELPs in their departments and that they would prefer these policies to be explicit and overt (see also Section 2.2). A very small proportion reported wanting to have non-written ELPs $(2.8 \%)$.

Table 8. What type ELPs should be

\begin{tabular}{|c|c|c|c|}
\hline Values & Frequency & Per cent & Valid Per cent \\
\hline Non-written & 6 & 2.8 & 2.8 \\
\hline Written & 201 & 96.4 & 96.4 \\
\hline Both & 1 & 0.4 & 0.4 \\
\hline Total & $\mathbf{2 0 8}$ & $\mathbf{1 0 0 . 0}$ & $\mathbf{1 0 0 . 0}$ \\
\hline
\end{tabular}




\subsubsection{My Department's Language Policies Should Be:}

\section{a) Agreed upon by the department council}

b) Set by some members informally

c) Other:..........

In response to this statement, the majority of the participants (89.6\%) reported that ELPs in their department should be agreed upon by the department council (see Table 9). This may suggest that they thought they should be official (i.e., explicit) and approved by all members of staff through the supreme authority at department level. This could also result in producing policies that are acceptable to all, since members of staff with different views and beliefs can be involved and considered. A small proportion $(10 \%)$ reported that ELPs should be made in an informal manner and by some members of staff only. This may suggest that they would prefer not to have formal policies so they do not have to follow them. It could also mean that they would prefer to have ELPs that are flexible in nature.

Table 9. How ELPs should be made

\begin{tabular}{|c|c|c|c|}
\hline Values & Frequency & Per cent & Valid Per cent \\
\hline $\begin{array}{c}\text { Agreed upon by the } \\
\text { department council }\end{array}$ & 187 & 89.6 & 89.6 \\
\hline $\begin{array}{c}\text { Set by some members } \\
\text { informally }\end{array}$ & 21 & 10 & 10 \\
\hline Other & 0 & 0 & 0 \\
\hline Total & $\mathbf{2 0 8}$ & $\mathbf{1 0 0 . 0}$ & $\mathbf{1 0 0 . 0}$ \\
\hline
\end{tabular}

\subsection{Institutional Implications}

Since Arabic is the national language in Saudi Arabia and is used for communication purposes in most areas of society, in addition to the fact that English is a foreign, not a second, language in the Kingdom, opportunities to speak English can be quite limited for those who wish to practise it (see Section 2.4). Other researchers have confirmed that, in an EFL context, the domains where professional use of, and authentic situations in which to practise, the English language can be rather limited [35, 20]. English departments in Saudi Arabia are one of the few domains where it is expected that English will be utilized extensively, since they comprise members of staff who hold different degrees in the English language and, therefore, are fluent in this language. The questions that arise are: how is the English language situated within the department (and outside the domain of the classroom) and how should it be practised? These practices constitute language policies that at some point might become of interest to some departments, institutions and even the Ministry of Education itself.

In an overall evaluation of the findings of this study, it was observed that the practice of ELPs has attracted the attention of members of staff in Saudi English departments, since when the responses were clustered the majority were indicative of a belief that ELPs should be put into practice in English departments, that they should be made explicit, and that they should be established at the micro level (see Table 10 and Section 2.2).

Table 10. Summary of results clustering

\begin{tabular}{|c|c|c|}
\hline No. & Main Interview Findings & $\begin{array}{c}\text { Response } \\
\text { Percentage }\end{array}$ \\
\hline 1 & $\begin{array}{l}\text { English should be used whenever } \\
\text { possible }\end{array}$ & $75 \%$ \\
\hline 2 & $\begin{array}{l}\text { The department should be the only } \\
\text { authority to make ELPs }\end{array}$ & $100 \%$ \\
\hline 3 & $\begin{array}{l}\text { ELPs are important to English } \\
\text { departments }\end{array}$ & $100 \%$ \\
\hline No. & Main Survey Findings & $\begin{array}{c}\text { Response } \\
\text { Percentage }\end{array}$ \\
\hline 1 & $\begin{array}{l}\text { It is a must to have ELPs in English } \\
\text { departments }\end{array}$ & $91.6 \%$ \\
\hline 2 & $\begin{array}{c}\text { Members of staff must abide by } \\
\text { ELPs }\end{array}$ & $92,1 \%$ \\
\hline 3 & $\begin{array}{l}\text { Staff members' familiarity with } \\
\text { ELPs can be beneficial }\end{array}$ & $91.6 \%$ \\
\hline 4 & $\begin{array}{l}\text { Institutions should require English } \\
\text { depts. to have ELPs }\end{array}$ & $90.2 \%$ \\
\hline 5 & $\begin{array}{l}\text { The chairman should ensure ELPs } \\
\text { are put into practice }\end{array}$ & $92.6 \%$ \\
\hline 6 & $\begin{array}{l}\text { English depts. should have written } \\
\text { ELPs }\end{array}$ & $96.4 \%$ \\
\hline 7 & $\begin{array}{l}\text { ELPs should be agreed upon by } \\
\text { dept. council }\end{array}$ & $89.6 \%$ \\
\hline
\end{tabular}

A glance at the summary table above suggests that the majority of the English departments in Saudi Arabia would want to include the practice of these policies as an integral part of their daily life, and that the use of English should not be limited to classrooms, which could be a result of the influence of the status of English in Saudi Arabia on these departments (see Section 2.3). It also suggests that ELPs should be set up using a systematic formal framework, which will ensure, to some extent, their practice and development in a way that contributes to the institution as a whole.

According to the interview responses, English should be used whenever possible since this will have a positive impact on a department as a whole. Using English can compensate for the lack of exposure to and opportunities to practise the language that can be encountered in an EFL context. In Saudi Arabia the practice of English can be limited to particular situations, so creating a daily context where English can be utilized with other professionals is bound to be beneficial. Therefore, it can be said that using English in an English department outside the classroom can create a professional working environment that is in line with institutional goals. This concurs with the findings from the survey, with $91.6 \%$ of the respondents reporting that staff members' familiarity with ELPs can contribute to the achievement of institutional goals. Thus, the recognition of ELPs and their existence are seen to be of importance and can be advantageous. Although members of English departments are fluent in English, using English more often and on a daily basis can contribute to maintaining as well as developing language proficiency 
$[22,31]$. Although members of staff are likely to practise English inside classrooms, still the nature of practice with students is different, in that with students a teacher might need to simplify syntactic structures, use simple vocabulary, repeat sentences, and so on, to compensate for students' modest proficiency levels. Therefore, the professional practice of language is likely to be with peers, i.e., staff members, with whom language practice can be very beneficial. Additionally, it is common to have non-Arabic speaking members in English departments (for example, some of the participants in this study were non-Arabic speakers, see Section 3.3), who attend department councils, other committee meetings, and so on (see Section 3.1). If there is no policy that English is to be used in their presence, other members of staff may use Arabic for communication and decision making and the non-Arabic speaking members will be marginalized. If issues concerning the department of which they are members are discussed in a language they do not understand, in effect their rights to participate and play their role are taken away.

After establishing the importance of the existence of ELPs, it was necessary for us to become familiar with department members' opinions on how the framework of these policies should be processed. First of all, the interviews revealed that most of the participants believed the department should be the only authority to make such policies, a finding that partially concurs with the survey findings. The only partial consistency of opinions here may be owing to the fact that the interviewees all held administrative positions (i.e., seven chairmen and one vice chair), and that chairmen have power and authority in decision making, as opposed to the majority of the survey respondents who are more involved in teaching than in administrative work. However, the majority of the survey respondents stated the opinion that the department should be involved in making ELPs, either as the only authority or in association with other parties (see Section 4.2.6). Here, it should be pointed out that most Saudi English departments opt for bottom-up processes when making ELPs, and only a few opt for top-down processes. In justifying why the department should be the authority that makes ELPs, the interviewees explained that making ELPs is an internal matter that concerns a department rather than a college or an institution. A department has English language experts who are more likely to know which policies it is feasible to practise and which will be beneficial. Additionally, when these policies emerge from within the department, they are likely to be more generally accepted and, therefore, practised more often, and, probably, nurtured and developed in the future. At institutional level, it is unlikely that decision makers will be English specialists; consequently, if ELPs are made by them, they may not be feasible or serve the purpose they were meant for.

With regard to the emergence of ELPs, it was suggested that the institutions should require their English departments to have them; therefore, such policies should become official (explicit) (see Section 2.2). This concurs with the other findings that the chairman should ensure their practice (during meetings and discussions, for instance), and that members should abide by them. Additionally, the majority of the participants stated that these policies should be agreed upon by the department council (the supreme council at department level, see Section 3.1) and that they should be in a written form. All of which shows that members of English departments need to have such policies established in an official manner. Making them official has several advantages. For example, these policies can be overt - that is to say, all members of staff can be aware of their existence since they have been approved by the council and provided in a written form (see Section 2.2). Also, through the council, the expertise of all members of staff can be utilized which means that policies of a high quality will be produced. It also means that it is more likely that they will be accepted by members of staff; thus, their success can to some extent be ensured, and they may be practised for a long period.

\section{Conclusions}

The study referred to in this paper explored Saudi English department staff members' beliefs concerning ELPs outside the domain of the classroom and at department level. It was found that Saudi departments have a preference for, and recognize the importance of, ELPs and that it is recommended that English be used on most, if not all possible occasions because of the positive impact this will have on the department. Not only were the participants in favour of ELPs, they wanted them to be official, in that they should be written down and efforts should be made to ensure they are put into practice. According to the findings of this study, the process by which they are made should start from within the department, not the institution. Additionally, it is recommended that the expertise of staff members be employed in making department policies, and that their awareness of the existence of ELPs should be raised.

It is hoped that the findings of the study offer insights into department practices concerning English and how these practices are seen. Institutions may take into account their English departments' views and preferences regarding these policies, and avoid attempts to enforce certain policies that may not serve the greater educational purpose. Allowing for flexibility in making department policies will increase mutual trust between the two parties (i.e., an institution and its department) that will in turn contribute to accomplishing institutional goals.

\section{REFERENCES}


[1] Alasmari, A. \& Khan, S. (2014). World Englishes in the EFL Teaching in Saudi Arabia. Arab World English Journal, 5(1), pp. 316-325.

[2] Alshammari, M. (2011). The Use of the Mother Tongue in Saudi EFL Classrooms. Journal of International Education Research, 7(4), pp. 95-102.

[3] Alsuhaibani, Y. (2015). The Perceptions and Practice of L1 Arabic in Saudi University English Classrooms. PhD thesis. University of Newcastle.

[4] Bisson, M. J., van Heuven, W. J., Conklin, K. \& Tunney, R. J. (2014). The Role of Repeated Exposure to Multimodal Input in Incidental Acquisition of Foreign Language Vocabulary. Language Learning, 64(4), pp. 855-877.

[5] Blommaert J. (2006). Language Policy and National Identity. In: T. Ricento (Eds.). An Introduction to Language Policy: Theory and Method. Malden, MA: Blackwell (pp. 238-54).

[6] Bright, W. (1992). Language Policy. International Encyclopedia of Linguistics. 4, pp. 310-311.

[7] Chang, C. P. \& Shu, M. Z. (2000). The Experiment Research for English Teaching with Small Class of Junior High School. (The Ministry of Education, The 2000 Academic Year Research Project of Taiwan High School Technician Conference).

[8] Cooper, R. L. (1989). Language Planning and Social Change. Cambridge, England: Cambridge University Press.

[9] Ferguson, C. A. (1968). Language Development. In: J. A. Fishman, C. A. Ferguson, \& J. Dasgupta (Eds.). Language Problems of Developing Nations. New York; London: Wiley (pp. 29-97).

[10] Firth, A. (1996). The Discursive Accomplishment of Normality on "Lingua Franca" English and Conversation Analysis. Journal of Pragmatics, 26, pp. 237-59.

[11] Fishman, J. A. (2002). Holy Languages' in the Context of Societal Bilingualism. Contributions to the Sociology of Language, 87, pp. 15-24.

[12] Hall, G. \& Cook, G. (2013). Own-Language Use in ELT: Exploring Global Practices and Attitudes. British Council, 10, pp. 1-48.

[13] Haugen, E. (1983). The Implementation of Corpus Planning: Theory and Practice. In: J. Cobarrubias \& J. A. Fishman (Eds.). Progress in Language Planning: International Perspectives. Berlin; New York: Mouton Publishers.

[14] Hornberger, N. (2006). Frameworks and Models in Language Policy and Planning. In: T. Ricento (Ed.). An Introduction to Language Policy: Theory and Method. Malden, MA: Blackwell Pub (pp. 24-41).

[15] Johnson, D. C. (2013). Language Policy, Hampshire: Macmillan, UK.

[16] Kaplan, R. B. \& Baldauf, R. B. (1997). Language Planning: From Practice to Theory. Clevedon: Multilingual Matters Ltd.

[17] Liddicoat, A. J. (2012). Language Planning as an Element of Religious Practice. Current Issues in Language Planning, 13(2), pp. 121-144.
[18] Mohamed, S. (2007). The Use of the L1 in Egyptian EFL Classrooms. $\mathrm{PhD}$ thesis. University of Salford.

[19] Paradis, J. (2010). Bilingual Children's Acquisition of English Verb Morphology: Effects of Language Exposure, Structure Complexity, and Task Type. Language Learning, 60(3), pp. 651-680.

[20] Parker, J. E., Heitzman, S. M., Fjerstad, A. M., Babbs, L. M. \& Cohen, A. D. (1995). Exploring the Role of Foreign Language in Immersion Education. In: D. Highland, P. W. Lee, J. Milcham \& R. R. Weber (Eds.). Second Language Acquisition Theory and Pedagogy. Mahwah, NJ: Lawrence Erlbaum Associates (pp. 235-253).

[21] Payne, M. \& Almansour, M. (2014). Foreign Language Planning in Saudi Arabia: Beyond English. Current Issues in Language Planning, 15(3), pp. 327-342.

[22] Pérez-Leroux, A. T., Munn, A., Schmitt C. \& DeIrish, M. (2004). Learning Definite Determiners: Genericity and Definiteness in English and Spanish. Boston University, Conference on Language Development, 28, Proceedings Supplement. http://www.bu.edu/linguistics/APPLIED/BUCLD/supp.ht $\mathrm{ml}$

[23] Ricento, T. (2013). Language Policy, Ideology and Attitudes in English-Dominant Countries. In: R. Bayley, R. Cameron \& C. Lucas (Eds.). The Oxford Handbook of Sociolinguistics. Oxford: Oxford University Press (pp. 525-543).

[24] Schiffman, H. F. (2010). South and Southeast Asia. In: J. A. Fishman \& O. Garcia (Eds.). Handbook of Language and Ethnic Identity: Disciplinary and Regional Perspectives. $2^{\text {nd }}$ edition, Oxford University Press (pp. 452-469).

[25] Schiffman, H. F. (1996). Linguistic Culture and Language Policy. London: Routledge.

[26] Seidlhofer, B. (2005). English as a Lingua Franca. ELT Journal, 59(4), pp. 339-341.

[27] Shohamy, E. (2006). Language Policy: Hidden Agendas and New Approaches. London and New York: Routledge.

[28] Sipra, A. (2013). Contribution of Bilingualism in Language Teaching. Canadian Centre of Science and Education Journal, 6(1), pp. 56-66.

[29] Song, Y. \& Andrews, S. (2009). The L1 in L2 Learning: Teachers' Beliefs and Practices. Muenchen: LINCOM Europa.

[30] Spolsky, B. (2004). Language Policy. Cambridge: Cambridge University Press.

[31] Spolsky, B. (1989). Consider for Second Language Learning. Oxford: Oxford University Press.

[32] Tang, J. (2002). Using the L1 in the English Classroom. Forum, 40, pp. 36-43.

[33] Van Dijk, T. A. (1998). Ideology: A Multidisciplinary Approach. London: Sage.

[34] Wardhaugh, R. \& Fuller, J. M. (2015). An Introduction to Sociolinguistics. $7^{\text {th }}$ edition, Chichester: Wiley Blackwell.

[35] Wu, W. \& Wu, P. (2008). Creating an Authentic EFL 
Learning Environment to Enhance Student Motivation to Study English. Asian EFL Journal, 10(4), pp. 211-222,
Conference Proceedings. 